\title{
Efektivitas Program Beras Untuk Rumah Tangga Miskin (RASKIN) di Provinsi Bali
}

\author{
Sudarsana Arka ${ }^{1)}$ \\ I Gusti Bagus Indrajaya ${ }^{1)}$
}

1) Fakultas Ekonomi dan Bisnis Universitas Udayana

\begin{abstract}
ABSTRAK
Penelitian ini bertujuan untuk mengevaluasi efektivitas pelaksanaan program beras untuk rumah tangga miskin (RASKIN) yang ada di Provinsi Bali. Program RASKIN merupakan salah satu program pengentasan kemiskinan yang diberlakukan secara reguler oleh pemerintah. Rumah tangga miskin yang menjadi sasaran program ini tidak langsung mendapat jatah beras secara gratis, namun masih harus membayar sejumlah uang untuk mendapatkan beras dengan harga yang relatif murah. Proses penyaluran beras yang tidak langsung ini banyak mendapat kritikan karena berpotensi akan menimbulkan salah sasaran (mistarget). Penelitian ini lebih fokus pada evaluasi dampak Program RASKIN terhadap tingkat kesejahteraan rumah tangga yang diukur dari indikator pendapatan rumah tangga serta pengeluaran rumah tangga. Data yang dikumpulkan berasal dari survei terhadap kurang lebih 500 responden yang berasal dari berbagai daerah di Provinsi Bali. Hasil penelitian menemukan bahwa rumah tangga yang mendapatkan Program RASKIN ternyata memiliki pendapatan serta pengeluaran yang lebih tinggi. Jika tingkat kesalahan target program ini diasumsikan sangat kecil, maka Program RASKIN dapat dikatakan memiliki pengaruh yang positif terhadap tingkat kesejahteraan.
\end{abstract}

Kata kunci: efektivitas program, RASKIN, rumah tangga, Bali

Klasifikasi JEL: C35, D7, J13

\section{Effectiveness of Rice for Poor Household Programs (RASKIN) in Bali Province}

\begin{abstract}
This study aims to evaluate the effectiveness of rice program implementation for poor households (RASKIN) in Bali Province. The RASKIN program is one of the poverty alleviation programs that are regularly enforced by the government. The poor households that were targeted by the program did not directly get the rice rations for free, but still had to pay some money to get rice at a relatively cheap price. The process of indirect rice distribution is much criticized because it would potentially lead to targetting error. This study focuses more on evaluating the impact of the RASKIN Program on the level of household welfare as measured by household income and household expenditures. The data collected came from a survey of approximately 500 respondents from various regions in Bali Province. The results of the study found that households receiving the RASKIN program turned out to have higher incomes and expenditures. If the target program error rate is assumed to be very small, then the RASKIN program can be said to have a positive effect on the level of household welfare
\end{abstract}

Keywords: effectiveness of programs, rice for poor, household, Bali

JEL classification: $C 35, D 7, J 13$

\section{PENDAHULUAN}

Program Beras Untuk Keluarga Miskin atau yang lebih dikenal sebagai Raskin merupakan program nasional yang bertujuan untuk membantu Rumah Tangga Miskin (RTM) dalam memenuhi kebutuhan pangan. Program ini merupakan kelanjutan dari Program Operasi Pasar Khusus
(OPK) yang awalnya didesain untuk mengurangi beban keuangan RTM akibat krisis ekonomi 1997. Sejak tahun 2002 OPK diubah menjadi Program Raskin karena sudah tidak lagi menjadi program darurat penanggulangan dampak krisis ekonomi sekaligus untuk mencerminkan sifat progam sebagai bagian dari social safety net programs 
bagi RTM (Mawardi, 2008). Evaluasi kebijakan Raskin selama ini lebih banyak menyorot masalah efektivitas pelaksanaan program seperti pencapaian indikator 6T; tepat sasaran, tepatjumlah, tepatharga, tepat waktu, tepat kualitas dan tepat administrasi. Sementara dampak kebijakan tersebut terhadap perubahan perilaku dan kesejahteraan penerima program belum dilakukan secara komprehensif.

Meskipun angka kemiskinan di Provinsi Bali dalam lingkup nasional relatif rendah, akan tetapi jumlah penduduk miskin masih cukup banyak. Berdasarkan data Badan Pusat Statistik (BPS), jumlah penduduk miskin di Provinsi Bali per Maret 2016 mencapai 178.000 orang. Dengan kata lain, masih terdapat $4,25 \%$ penduduk Bali yang masih dikategorikan sebagai penduduk miskin. Sebagai salah satu program unggulan pengentasan kemiskinan, Program Raskin tentu diharapkan mampu mengurangi masalah kemiskinan secara lebih jauh. Untuk itu, evaluasi secara menyeluruh terhadap program ini tentunya sangat diperlukan.

Dalam peranannya sebagai penyangga penurunan konsumsi beras selama krisis ekonomi, Program Raskin memang terbukti sangat menguntungkan masyarakat miskin. Akan tetapi ketika program ini dilanjutkan pasca krisis, harus dilakukan evaluasi secara menyeluruh dampak jangka panjang program terhadap perubahan perilaku masyarakat. Terlebih, terdapat indikasi bahwa program ini dalam taraf tertentu banyak mengalami apa yang kemudian dikenal sebagai targeting error. Berdasarkan kajian yang hati-hati, Barrett (2002) menjelaskan bahwa targeting error bisa jadi merupakan salah satu penyebab program pemerintah memiliki dampak negatif khususnya dalam hal penyediaan tenaga kerja (labor supply) atau work effort.

Program bantuan pangan bagaimanapun dilakukan dengan motif kemanusiaan. Barret dan Maxwell (2005) secara lebih spesifik menjelaskan bahwa program bantuan pangan pada hakekatnya memiliki dua peran penting dalam kondisi darurat (emergency) serta tujuan pengembangan (developmental). Namun demikian, sebagaimana disitir oleh Sulaiman (2010), program semacam ini ini juga berpotensi untuk memiliki dampak yang kurang diharapkan. Dampak sampingan yang mungkin muncul diantaranya adalah disincentive untuk bekerja dan crowding-out effect terhadap bantuan pangan yang sebelumnya diterima rumah tangga dari keluarganya (private transfer) maupun dari lembaga swadaya masyarakat. Sejumlah penelitian menunjukkan bahwa kecurigaan efek negatif ini bukanlah sesuatu yang mengada-ada. Sulaiman (2010) menemukan bukti bahwa program bantuan makanan justru menurunkan tingkat pendapatan keluarga di Sudan. Hasil yang kurang lebih sama juga ditemukan di Sri Lanka oleh Sahn dan Alderman (1996) yang menyimpulkan bahwa subsidi pangan justru menurunkan work effort dan juga pendapatan.

Tidak hanya berimplikasi negatif dalam bentuk penurunan pendapatan keluarga, program bantuan pemerintah juga dipercaya memiliki efek mendesak atau mengurangi (crowdedout effect) bantuan pangan dari pihak lain baik dari perseorangan maupun dari lembaga nonpemerintah. Penelitian Lal dan Sharma (2009) membuktikan adanya efek ini dalam kasus bantuan pemerintah di daerah pedesaan India. Sementara di Nicaragua dan Honduras, Nielson dan Olinto (2007) juga menemukan bukti kuat bahwa pemberian bantuan tunai pemerintah terbukti mengurangi bantuan pangan oleh anggota keluarga lain dan juga bantuan dari LSM setempat. Dalam taraf tertentu crowding-out effect justru berpotensi menimbulkan masalah bagi pemerintah itu sendiri mengingat tujuan program akan relatif sulit untuk mencapai sasarannya. Hasil penelitian mengenai dampak disinsentif maupun crowding-out effect sebenarnya tidak selalu memberikan hasil yan konsisten. Beberapa penelitian di tempat berbeda juga memberikan hasil yang berbeda-beda. Meski demikian, hasil penelitian yang sejenis dengan kasus di Indonesia relatif masih terbatas.

Sebagai program yang secara khusus ditujukan untuk menangani kemiskinan, evaluasi terhadap kebijakan Raskin sangat penting untuk dilakukan. Terlebih, pada beberapa periode terakhir, angka kemiskinan di Indonesia relatif tidak banyak berubah. Pada tahun 2015, angka kemiskinan mencapai 11,22 persen atau setara dengan 28 juta lebih jiwa. Meskipun angka kemiskinan di Provinsi Bali relatif lebih rendah daripada angka kemiskinan nasional, namun masalah kemiskinan tidak dapat diabaikan.

Program Raskin merupakan program nasional yang bertujuan membantu memenuhi kecukupan pangan dan mengurangi beban finansial rumah tangga miskin melalui penyediaan beras bersubsidi. Sejak 2007, Menteri Koordinator Kesejahteraan Rakyat menjadi 
koordinator pelaksanaan Program Raskin. Untuk pendistribusian beras, Badan Urusan Logistik (Bulog) bertanggung jawab mendistribusikan beras hingga titik distribusi, dan pemerintah daerah bertanggungjawab menyalurkan beras dari titik distribusi kepada rumah tangga miskin.

Pada tahun 2007, Program Raskin menargetkan penyediaan 1,9 juta ton beras bagi 15,8 juta rumah tangga miskin dengan total anggaran $\mathrm{Rp}$ 6,28 triliun yang bersumber dari APBN. Setiap rumah tangga sasaran menerima $10 \mathrm{~kg}$ beras setiap bulan dengan harga Rp 1.000 per kilogram di titik distribusi. Program Raskin pada dasarnya merupakan kelanjutan dari Program Operasi Pasar Khusus (OPK) yang diluncurkan pada Juli 1998 di bawah Program Jaring Pengaman Sosial (JPS). Selama sembilan tahun pelaksanaan Program Raskin, berbagai pihak telah melakukan evaluasi dan hasilnya telah memberikan input bagi perbaikan konsep dan pelaksanaan program. Beberapa penyesuaian yang telah dilakukan antara lain meliputi perubahan nama, jumlah beras per rumah tangga, frekuensi distribusi, sumber dan jenis data sasaran penerima manfaat, dan penyediaan lembaga pendamping.

Pada 2002, pemerintah mengganti nama OPK menjadi Program Raskin agar lebih mencerminkan sifat program, yakni sebagai bagian dari program perlindungan sosial bagi RTM, tidak lagi sebagai program darurat penanggulangan dampak krisis ekonomi. Penetapan jumlah beras per bulan per RTM yang pada awalnya $10 \mathrm{~kg}$, selama beberapa tahun berikutnya bervariasi dari $10 \mathrm{~kg}$ hingga $20 \mathrm{~kg}$, dan pada $2007 \mathrm{kembali}$ menjadi $10 \mathrm{~kg}$. Frekuensi distribusi yang pada tahuntahun sebelumnya 12 kali, pada 2006 berkurang menjadi 10 kali, dan pada 2007 kembali menjadi 12 kali per tahun. Sasaran penerima manfaat yang sebelumnya menggunakan data keluarga pra-sejahtera (KPS) dan keluarga sejahtera 1 (KS-1) alasan ekonomi hasil pendataan BKKBN, sejak 2006 berubah menggunakan data RTM hasil pendataan BPS melalui PSE-05. Selain itu, dalam rangka meningkatkan kinerja pelaksanaan program, pada 2005 dan 2006 Bulog melakukan kerja sama dengan sepuluh perguruan tinggi negeri untuk memberikan pendampingan terhadap pelaksanaan Program Raskin di 12 provinsi.

Kajian mengenai efektifitas pelaksanaan Program Raskin di Indonesia pernah dilakukan oleh SMERU (Mawardi, 2008). Hasil kajian menunjukkan bahwa masalah distribusi dan ketepatan target merupakan salah satu masalah yang relatif sulit dipenuhi. Adanya beberapa kendala yang dialami di lapangan mengakibatkan terhambatnya penyaluran sekaligus mengakibatkan berbagai macam sasaran program, terutama sasaran harga tidak dapat dipenuhi secara memuaskan. Secara umum, hasil kajian terhadap pelaksanaan Program Raskin menunjukkan bahwa efektivitas program masih relatif lemah. Hal ini ditandai oleh sosialisasi dan transparansi yang kurang memadai; target penerima, harga, jumlah, dan frekuensi penerimaan beras yang kurang tepat; biaya pengelolaan program yang tinggi; pelaksanaan pemantauan yang belum optimal; dan mekanisme pengaduan yang kurang berfungsi Mawardi dkk (2008).

Sejumlah kajian mengenai dampak program bantuan pangan telah banyak dilakukan. Dengan melakukan kajian review literatur, Lentz (2003) tidak dapat menemukan hubungan yang pasti berkaitan dengan efek disinsentif dari program, sementara efek crowding-out program pangan terhadap bantuan informal ditelaah oleh Dercon dan Krishnan (2003). Dengan melakukan kritik metodologi terhadap kajian sebelumnya (Sahn \& Alderman, 1996), Abdulai dkk (2005) meneliti dampak program pangan terhadap penawaran tenaga kerja. Dengan menggunakan data cross-section Ethiopia dan melakukan kontrol terhadap karakteristik rumah tangga mereka menemukan bahwa tidak cukup bukti untuk menyatakan adanya efek disinsentif. Akan tetapi penelitian tersebut masih belum lepas dari isu endogenitas partisipasi program. Penelitian yang lebih komprehensif dilakukan oleh Gilligan dan Hoddinott (2007) untuk menguji dampak program terhadap produktivitas melalui perubahan status nutrisi, efeknya terhadap akumulasi aset dan pemutusan lingkaran kemiskinan. Dengan latar pendekatan randomize evaluation, Skoufias dkk (2008) menemukan bukti bahwa program baik berupa transfer uang maupun makanan tidak memiliki dampak terhadap partisipasi kerja di Mexico. Tadesse dan Shively (2009) melakukan kajian mengenai hubungan antara program dengan produksi lokal melalui efek harga.

Sebagaimana telah disinggung bahwa Sulaiman (2010) menguji dampak program bantuan pangan terhadap insentif kerja dan bantuan pangan dari dan ke pihak famili non-anggota rumah 
tangga di Sudan. Hasil penelitian menunjukkan bahwa program berimplikasi pada penurunan anak bekerja, namun sebagai konsekwensinya pendapatan total keluarga menjadi menurun. Penelitian ini didasarkan atas program yang di desain secara random. Program juga tidak menyebabkan adanya crowding-out effect. Peneliti berargumen bahwa relatif kecilnya jumlah transfer berakibat tidak ditemukannya efek ini. Jangka waktu evaluasi yang sangat pendek (satu tahun, 2008-2009) menyebabkan hasil kajian tidak bisa menangkap efek jangka panjang dari program.

Khusus untuk pengujian efek crowdingout secara umum juga telah banyak dilakukan. Kang dan Suwada (2003) dengan kajian terhadap perekonomian Korea Selatan, menemukan bukti bahwa efek crowding-out sangat signifikan. Hasil yang berbeda ditemukan oleh Kang (2004) dalam perekonomian Nepal. Meskipun menemukan motif transfer yang sama seperti di Korea Selatan, efek crowding-out tidak ditemukan secara signifikan. Peneliti berargumen bahwa besarnya transfer mempengaruhi perbedaan hasil antara dua kasus diatas. Penelitian Nielsen dan Olinto (2007) untuk Nicaragua dan Honduras menemukan evidence yang cukup signifikan dalam hal efek crowding-out program transfer pemerintah tidak hanya terhadap transfer uang dan makanan dari pihak keluarga namun juga terhadap bantuan dari lembaga nonpemerintah. Bukti adanya efek ini juga ditemukan oleh Lal dan Sharma (2009) di pedesaan India. Penelitian terbaru dari Gerardi dan Tsai (2010) di Taiwan juga menemukan efek crowding-out dari program transfer pemerintah. Hasil penelitian menunjukkan bahwa efek disinsentif dari program pemerintah lebih banyak dibuktikan di negaranegara berkembang sementara efek mendesak atau crowding-out ditemukan di berbagai kasus baik di negara berkembang maupun di negara maju sekalipun.

Efek transfer terhadap penawaran tenaga kerja telah banyak dibahas dalam teori (Blundell \& MaCurdy, 2000). Dalam model penawaran tenaga kerja statis sederhana, peningkatan pendapatan di luar kerja akan mempengaruhi keputusan bekerja dengan cara menggeser kurva anggaran keluar dari titik origin. Jika bantuan menambah penghasilan seseorang maka dia akan menjadi lebih makmur dan akan meningkatkan konsumsi barang sekaligus memperbanyak leisure. Akibatnya bantuan akan menyebabkan efek disinsentif untuk bekerja.
Besarnya efek disinsentif ini tergantung dari beberapa faktor diantaranya asumsi model yang digunakan, peta preferensi individu serta besar dan struktur dari transfer.

Berdasarkan diskusi mengenai Program Raskin, baik dalam lingkup nasional maupun dalam lingkup daerah Provinsi Bali, serta memperhatikan beberapa kajian studi empiris sebelumnya di berbagai negara, maka tujuan dari penelitian ini secara singkat dapat diuraikan sebagai berikut:

1. Untuk mengevaluasi kinerja penargetan penerima program beras untuk rumah tangga miskin (Program Raskin) secara komprehensif di Provinsi Bali.

2. Untuk mengevaluasi dampak Program Raskin terhadap indikator subjektif kesejahteraan masyarakat di Provinsi Bali. Dalam hal ini indikator kesejahteraan yang digunakan adalah tingkat pendapatan rumah tangga serta tingkat pengeluaran rumah tangga.

\section{DATA DAN METODOLOGI}

Penelitian ini akan menggunakan data primer hasil survey rumah tangga di Provinsi Bali dengan menggunakan pendekatan proporsional sampling. Dalam hal ini setiap kabupaten/kota akan diwakili oleh sejumlah rumah tangga secara proporsional berdasarkan jumlah rumah tangga di masing-masing kabupaten/kota di Provinsi Bali. Setelah ditentukan jumlah rumah tangga yang akan disurvey, selanjutnya pemilihan rumah tangga survey dilakukan secara acak (random). Kepada sejumlah rumah tangga terpilih dilakukan wawancara untuk mendapatkan informasi penting terkait dengan jumlah beras Raskin yang diterima oleh rumah tangga pada periode penelitian. Data rumah tangga lain juga ditanyakan seperti tingkat penghasilan, jenis pekerjaan, tingkat pendidikan, jumlah tanggungan dan informasi sosio ekonomi lainnya yang relevan.

Tabel 1 menyajikan data terkait rumah tangga yang diwawancarai dalam penelitian ini. Responden berasal dari semua kabupaten/kota di Provinsi Bali. Dengan pertimbangan efisiensi biaya dan efektivitas waktu, dipilih sebanyak 533 rumah tangga untuk diwawancarai. Sebanyak 17\% responden menyatakan mendapatkan beras Raskin, sementara $82 \%$ menyatakan tidak menerima Raskin. Diantara responden tersebut, terdapat juga kepala rumah tangga yang menjawab tidak tahu.

Program Raskin tidak didesain secara 
Tabel 1. Rumah Tangga Populasi dan Sampel

\begin{tabular}{cccc}
\hline No & Kabupaten/Kota & Populasi & Sampel \\
\hline 1 & Jembarana & 77,534 & 2 \\
2 & Tabanan & 114,291 & 45 \\
3 & Badung & 95,553 & 20 \\
4 & Gianyar & 90,750 & 8 \\
5 & Klungkung & 47,168 & 64 \\
6 & Bangli & 50,691 & 21 \\
7 & Karangasem & 114,986 & 112 \\
8 & Buleleng & 172,540 & 162 \\
9 & Denpasar & 116,172 & 99 \\
\hline & Total & $\mathbf{8 7 9 , 6 8 5}$ & $\mathbf{5 3 3}$ \\
\hline
\end{tabular}

randomize sehingga outcome antara kelompok penerima Raskin (treatment) dengan kelompok non-penerima (control) tidak bisa dibandingkan secara langsung dengan menggunakan teknik regresi biasa (OLS). Untuk mengatasi isu endogeneity karena desain program yang jelas membedakan karakterisktik kelompok treatment dan kelompok kontrol, maka strategi estimasi yang biasa digunakan adalah menggunakan pendekatan duoble-difference atau difference in difference. Beberapa variabel penjelas yang digunakan adalah karakteristik rumah tangga yang terdiri atas usia kepala keluarga, jenis kelamin, tingkat pendidikan serta status pernikahan kepala rumah tangga.

Menggunakan model Sulaiman (2010) pendekatan model double difference yang digunakan dalam model bantuan pangan adalah sebagai berikut:

$y_{i t}=\beta_{0}+\beta_{1}$ treat $_{i}+\beta_{2}$ followup $_{t}+\beta_{3}$ treat $*$ followup $+\delta_{k} X_{i}$

Variabel treat menunjukkan apakah rumah tangga mendapat program $(=1)$ atau tidak $(=0)$, sementara follow-up menunjukkan tahun observasi. Koefisien interaksi treat dengan followup tidak lain merupakan koefisien double difference yang menjadi interest utama dalam penelitian ini. Karakteristik rumah tangga, $X$, juga digunakan sebagai variabel kontrol. Beberapa isu penting terkait dengan estimasi adalah permasalahan endogenity yang berpotensi menghasilkan estimator yang bias. Untuk mengatasi masalah ini, biasa digunakan pendekatan fixed effect dengan asumsi bahwa perilaku un-observed variables yang berkorelasi dengan variabel program adalah konstan antar waktu.

Mengikuti Sulaiman (2010), variabel outcome yang akan digunakan dalam penelitian ini adalah pendapatan rumah tangga dari bekerja, keikutsertaan anggota rumah tangga dalam aktivitas bekerja serta besarnya transfer pangan yang diberikan rumah tangga lain (private transfer). Tanda dan signifikansi dari koefisien $\beta_{3}$ akan menjadi indikator penting dari evaluasi. Tanda minus (dan signifikan) dari koefisien tersebut akan membuktikan hipotesis disincentive dan crowingout dari adanya program Raskin. Dengan kata lain, program bantuan pangan tersebut secara umum justru mengakibatkan orang untuk lebih malas bekerja (disincentive) dan mengurangi jatah bantuan pangan dari rumah tangga lain (crowdingout).

Variabeloutcome dalam penelitian ini terdiri atas pengeluaran konsumsi beras, pendapatan dari bekerja seluruh rumah tangga, status kerja kepala rumah tangga, jumlah anggota keluarga yang bekerja serta rata-rata waktu bekerja anggota keluarga setahun dalam minggu. Sementara itu untuk menguji efek crowding-out, penelitian ini fokus pada transfer pangan (dalam bentuk uang) dari anak (tepatnya, non-coresident children) kepada orang tuanya. Besarnya transfer dihitung berdasarkan selisih positif antara jumlah transfer pangan yang diterima dengan yang diberikan.

Penggunaan model Sulaiman (2010) sebagaimana dalam persamaan (1) diatas memiliki beberapa permasalahan. Pertama, data yang dibutuhkan untuk menerapkan metode tersebut harus berupa data panel untuk minimal dua periode pengamatan. Kedua, model tersebut membutuhkan banyak outcome untuk program yang diteliti sehingga kemungkinan terjadinya salah pengukuran, observasi tak terjawab serta hal lain lebih banyak ditemukan. Dengan beberapa pertimbangan tersebut diatas, maka model analisis yang dipilih relatif lebih sederhana, yakni:

$y_{i v}=\beta_{0}+\beta_{1}$ Raskin $_{i v}+\boldsymbol{\delta}_{\boldsymbol{k}} \boldsymbol{X}_{i v}+\emptyset_{v}+\varepsilon_{i v}$ (2)

Model tersebut diatas menyatakan bahwa outcome dari program $\left(y_{i v}\right)$ ditentukan oleh keikutsertaan rumah tangga dalam Raskin serta berbagai karakteristik rumah tangga $\left(\boldsymbol{X}_{i v}\right)$ serta karakteristik lain yang berada dalam level komunitas. Karakteristik rumah tangga dalam hal ini diwakili oleh vektor karakteristik seperti pendidikan, usia, status pernikahan serta jumlah tanggungan.

Sementara itu, karakteristik atau variabel yang mempengaruhi indikator kesejahteraan dalam level komunitas, diwakili oleh variabel $\left(\emptyset_{v}\right.$ ). Problem estimasi dari persamaan (2) adalah 
Tabel 2. Indeks Kedalaman dan Keparahan

Kemiskinan di Bali

\begin{tabular}{lccc}
\hline $\begin{array}{c}\text { Periode } \\
(1)\end{array}$ & $\begin{array}{c}\text { Kota } \\
(2)\end{array}$ & $\begin{array}{c}\text { Desa } \\
(3)\end{array}$ & $\begin{array}{c}\text { Kota+Desa } \\
(4)\end{array}$ \\
\hline $\begin{array}{llll}\text { Indeks Kedalaman Kemiskinan (P1) } \\
\quad\end{array}$ & & \\
$\quad$ September 2015 & 1,090 & 1,198 & 1,131 \\
$\quad$ Maret 2016 & 0,450 & 0,616 & 0,511 \\
$\begin{array}{l}\text { Indeks Keparahan Kemiskinan (P2) } \\
\quad \text { September 2015 }\end{array}$ & 0,351 & 0,336 & 0,345 \\
$\quad$ Maret 2016 & 0,078 & 0,118 & 0,093 \\
\hline
\end{tabular}

Diolah dari Susenas September 2015 dan Maret 2016.

tidak semua variabel dalam level komunitas dapat diestimasi secara langsung baik oleh karena tidak tersedianya data maupun karena desain pengambilan sampel yang hanya berkutat pada level individu. Problem ini akan menjadi semakin kompleks jika variabel yang tidak terobservasi tersebut ternyata berkorelasi dengan variabel utama.

Solusi yang dilakukan untuk mengatasi masalah estimasi tersebut adalah sebagai berikut. Pertama, dilakukan isolasi dengan memasukkan unsur $\emptyset_{v}$ ke dalam konstanta.

$y_{i v}=\left[\beta_{0}+\emptyset_{v}\right]+\beta_{1}$ Raskin $_{i v}+\boldsymbol{\delta}_{\boldsymbol{k}} \boldsymbol{X}_{i v}+\varepsilon_{i v}$ (3)

Memasukkan variabel $\emptyset_{v}$ ke dalam model dapat dilakukan dengan menambahkan dummy wilayah ke dalam model. Pendekatan estimasi ini dikenal sebagai Least Square Dummy Variables (LSDV) atau juga dikenal sebagai Fixed Effect (FE). Dengan pendekatan ini maka problem endogeneity dapat diselesaikan.

Solusi lain adalah memasukkan unsur $\emptyset_{v}$ ke dalam bagian error. Oleh karena itu, dalam model akan terdapat komposit error yang meliputi error sejati (white noise) serta error yang berasal dari variasi antar wilayah.

$y_{i v}=\beta_{0}+\beta_{1}$ Raskin $_{i v}+\boldsymbol{\delta}_{\boldsymbol{k}} \boldsymbol{X}_{i v}+\left[\emptyset_{v}+\varepsilon_{i v}\right](4)$

Pendekatan estimasi yang dilakukan dengan basis persamaan (4) dikenal sebagai pendekatan Random Effect (RE). Pendekatan ini bisa dipilih hanya dan hanya jika tidak terdapat indikasi adanya korelasi antara faktor yang diisolasi tersebut dengan variabel bebas utama. Jika korelasi ini tidak dapat diabaikan, maka penggunaan RE akan menghasilkan estimator yang bias.

Pemilihan model estimasi yang paling relevan dapat dilakukan dengan beberapa test. Pada intinya, penentuan estimasi yang paling cocok sebenarnya dapat dilakukan dengan melihat besaran estimasi dari masing-masing pendekatan. Jika hasil estimasi antara FE dengan RE sangat berbeda secara signifikan, maka indikasi endegeneous tidak dapat diabaikan. Dalam hal ini estimasi yang paling relevan adalah Fixed Effect (FE). Sebaliknya, jika hasil estimasi antara FE dengan RE tidak jauh berbeda, maka estimasi RE dapat digunakan. Dalam kasus ini, standar error masing-masing koefisien regresi adalah yang paling efisien. Paper ini tidak menguji penggunaan estimasi secara detail, namun akan menyajikan beberapa pendekatan sekaligus untuk pembandingan.

\section{HASIL DAN PEMBAHASAN}

Sebagai program yang secara khusus ditujukan untuk menangani kemiskinan, evaluasi terhadap kebijakan Raskin sangat penting untuk dilakukan. Terlebih, pada beberapa periode terakhir, angka kemiskinan di Indonesia relatif tidak banyak berubah. Pada tahun 2015, angka kemiskinan mencapai 11,22 persen atau setara dengan 28 juta lebih jiwa. Meskipun angka kemiskinan di Provinsi Bali relatif lebih rendah daripada angka kemiskinan nasional, namun masalah kemiskinan tidak dapat diabaikan.

Data pada Tabel 2 menunjukkan bahwa indeks kedalaman kemiskinan (P1) dan indeks keparahan kemiskinan (P2) selama periode September 2015 - Maret 2016 mengalami penurunan. Akan tetapi, indikator kemiskinan di daerah perkotaan relatif lebih rendah dibandingkan dengan daerah pedesaan. Masalah kemiskinan di Bali tidak hanya berkaitan dengan besaran kemiskinan itu sendiri, akan tetapi juga semakin besarnya kesenjangan antar daerah.

Sebagai salah satu upaya untuk mengatasi kemiskinan di Provinsi Bali, maka Program Raskin, sebagai salah satu program unggulan anti kemiskinan di Bali, dilaksanakan secara reguler 
Tabel 3. Estimasi Dampak Raskin Terhadap

Pendapatan

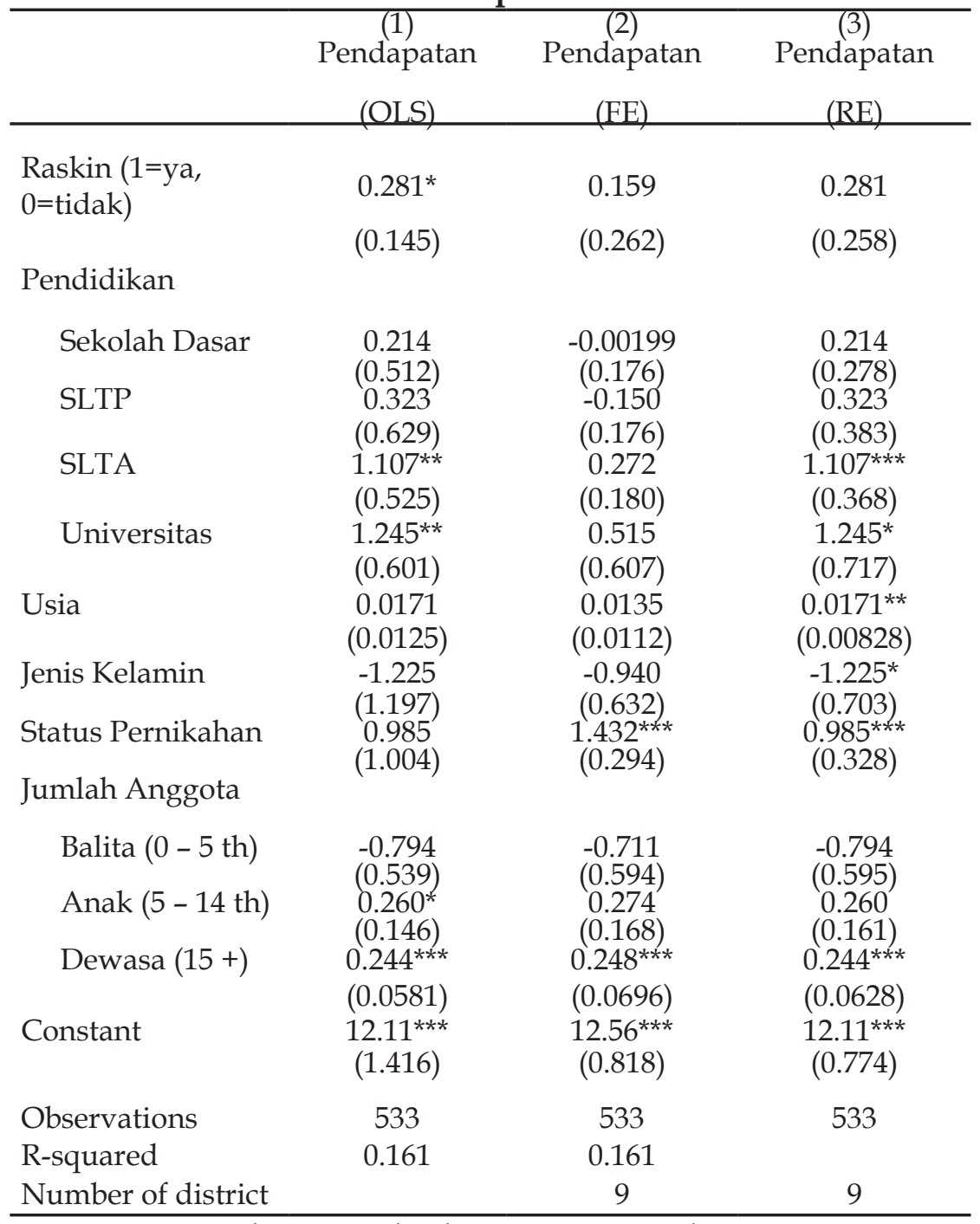

Robust standard errors in parentheses

${ }^{* * *} \mathrm{p}<0.01,{ }^{* *} \mathrm{p}<0.05,{ }^{*} \mathrm{p}<0.1$

selama beberapa tahun. Dampak program tersebut terhadap indikator kesejahteraan masyarakat dapat diperhatikan dari hasil analisis data yang secara rinci dapat diperhatikan dalam pembahasan berikut:

Hasil estimasi model dampak Program Raskin sebagaimana disajikan dalam Tabel 3 diatas dilaporkan dalam tiga kolom. Kolom (1) menyajikan hasil estimasi OLS; kolom (2) menyajikan hasil estimasi Fixed Effect (FE) dan kolom (3) menyajikan hasil estimasi menggunakan pendekatan Random Effect (RE). Hasil estimasi disajikan secara sejajar untuk dapat dilakukan perbandingan antar berbagai teknik estimasi yang dilakukan.

Model estimasi OLS menunjukkan bahwa Program Raskin memiliki korelasi positif terhadap pendapatan rumah tangga. Signifikansi yang dihasilkan relatif lemah (signifikan dalam taraf
$10 \%)$. Tingkat pendidikan yang memiliki pengaruh signifikan terhadap pendapatan rumah tangga adalah pendidikan setara SLTA dan Perguruan Tinggi (universitas). Beberapa karakteristik rumah tangga yang diwakili kepala rumah tangga antara lain tingkat usia, jenis kelamin, status pernikahan dan jumlah anggota rumah tangga tidak cukup signifikan.

Estimasi Fixed Effect (FE) juga menghasilkan estimasi yang tidak banyak signifikan. Dengan pendekatan FE ditemukan bahwa Program Raskin terbukti tidak memiliki pengaruh signifikan terhadap pendapatan rumah tangga. Kecuali status pernikahan dan jumlah tanggungan usia dewasa, tidak ada variabel bebas yang memiliki pengaruh signifikan terhadap tingkat pendapatan rumah tangga. Fixed Effect dalam hal ini dinyatakan dalam level kabupaten/ kota atau distrik. Untuk kasus Provinsi Bali, 
Tabel 4. Estimasi Dampak Raskin Terhadap Pengeluaran

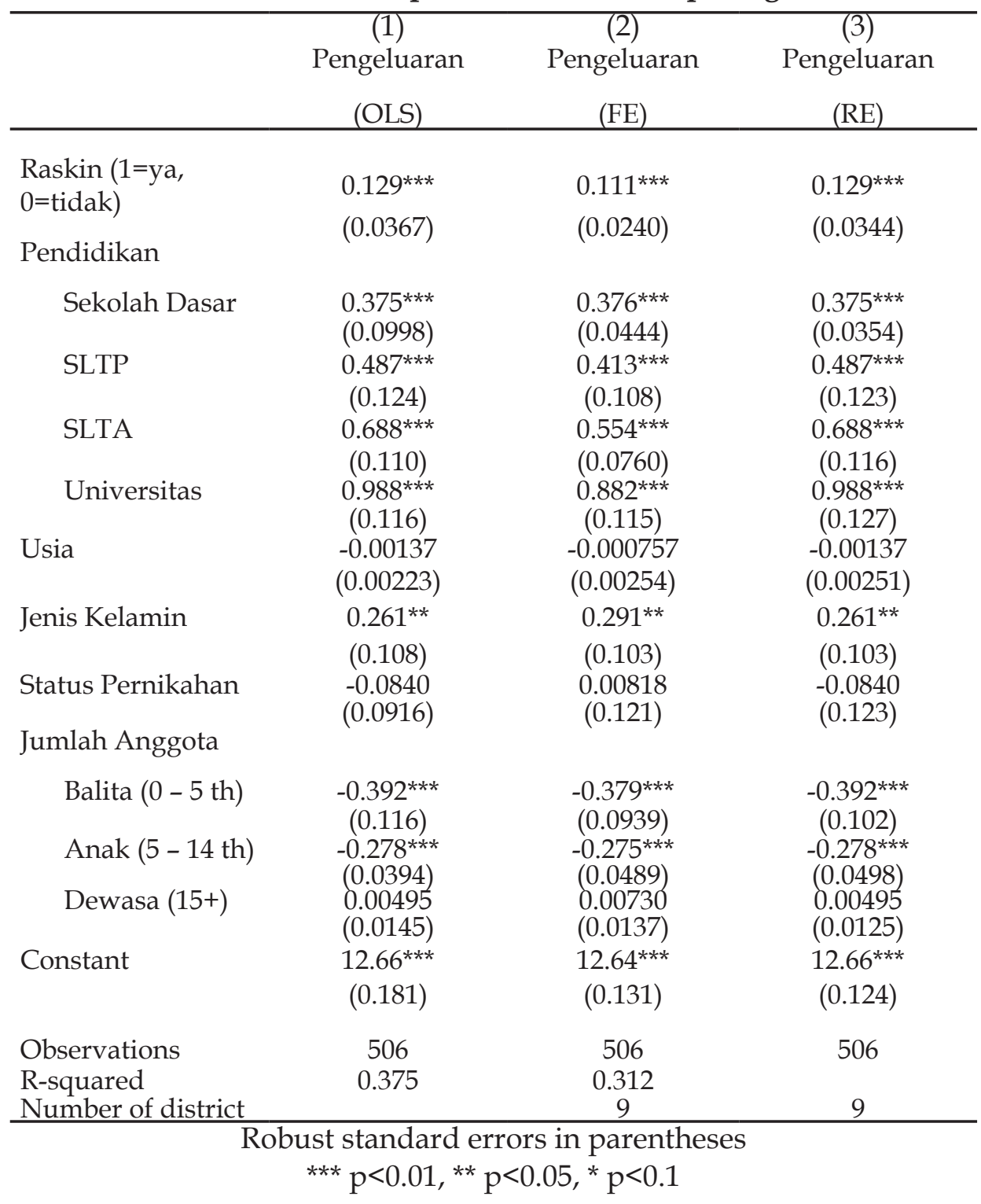

terdapat 9 kabupaten/kota yang dapat dianalisis.

Demikian halnya dengan hasil estimasi menggunakan Random Effect (RE). Program Raskin juga tidak berpengaruh signifikan terhadap peningkatan pendapatan rumah tangga. Terdapat beberapa variabel yang signifikan seperti tingkat pendidikan, usia kepala rumah tangga, status pernikahan dan jumlah anggota rumah tangga dewasa. Semua faktor-faktor karakteristik rumah tangga tersebut memang secara teori memiliki pengaruh yang signifikan terhadap pendapatan rumah tangga. Namun demikian, variabel utama dari penelitian ini justru tidak memiliki pengaruh yang signifikan.

Pemilihan variabel pendapatan rumah tangga sebagai indikator tingkat kesejahteraan rumah tangga memiliki beberapa masalah. Pertama, indikator ini hanya mewakili jumlah pendapatan dari hasil bekerja. Padahal pendapatan rumah tangga juga bisa berasal dari yang bukan bekerja (seperti hasil dari sewa aset, warisan, hadiah dan lain sebagainya). Kedua, pelaporan pendapatan sering undervalued karena sebagian responden bekerja di bidang non-formal sehingga pendapatan sering berubah dan tidak tetap. Ketiga, secara kultural, masyarakat Indonesia, termasuk Bali tentunya, lebih tertutup terhadap informasi pendapatan karena terdapat perasaan sungkan dan sebagainya.

Sebagai perbandingan, model analisis yang digunakan dalam penelitian ini juga menggunakan variabel pengeluaran rumah tangga sebagai variabel terikat. Estimasi juga dilakukan menggunakan tiga strategi yakni OLS, Fixed Effect (FE) dan Random Effect (RE). Hasil estimasi seluruhnya dapat diperhatikan dalam Tabel 4.

Hasil estimasi yang paling mencolok untuk dilihat adalah koefisien dari variabel utama, 
yakni Raskin. Hasil estimasi secara konsisten menunjukkan bahwa terdapat hubungan positif antara keikutsertaan dalam Program Raskin dengan tingkat pengeluaran rumah tangga. Rumah tangga yang memperoleh Beras Raskin secara rata-rata memiliki tingkat pengeluaran yang lebih tinggi. Taksiran estimasi menunjukkan bahwa perbedaan tingkat pengeluaran konsumsi yang terjadi meliputi 11 persen sampe 12 persen.

Korelasi positif antara perolehan Raskin dengan tingkat pengeluaran tidak hanya terjadi untuk kasus estimasi OLS, namun juga untuk kasus estimasi Fixed Effect dan Random Effect. Indikator pendidikan juga memiliki korelasi positif dengan tingkat pengeluaran. Besaran koefisien variabel pendidikan juga konsisten dengan logika teori. Semakin tinggi tingkat pendidikan rata-rata rumah tangga, maka semakin tinggi pula tingkat pengeluaran yang dilakukan. Kepala rumah tangga laki-laki secara rata-rata memiliki tingkat pengeluaran lebih tinggi. Rumah tangga dengan jumlah anggota rumah tangga balita lebih banyak ternyata lebih sedikit tingkat pengeluarannya. Rumah tangga tipe seperti ini biasanya rumah tangga baru yang belum banyak tingkat keperluannya.

Untuk membandingkan performa model estimasi dalam Tabel 3 dengan yang ada di Tabel 4 maka dapat dilakukan beberapa test. Indikator utama yang dapat dibandingkan adalah $R$-square. Model estimasi dalam Tabel 3 memghasilkan nilai $R$-square rata-rata sebesar $16 \%$. Sebaliknya model estimasi dalam Tabel 4 menghasilkan nilai $R$-square rata-rata sebesar lebih dari $30 \%$. Untuk tipe data cross-section, besaran $R$-square sebagaimana dihasilkan dalam Tabel 4 relatif cukup tinggi. Hal ini dengan jelas menunjukkan bahwa model estimasi dalam Tabel 4 dengan menggunakan variabel pengeluaran rumah tangga sebagai variabel terikat relatif lebih unggul.

Berdasarkan diskusimengenaihasilestimasi regresi maka dengan jelas dapat ditunjukkan bahwa Program Raskin lebih berdampak pada peningkatan pengeluaran rumah tangga dibandingkan dengan pendapatan rumah tangga. Selain masalah teknis metodologi sebagaimana disinggung pada bagian sebelumnya, hasil ini bisa diakibatkan oleh karena Program Raskin memang dirancang untuk mempertahankan tingkat konsumsi masyarakat akibat krisis dan bukan untuk penciptaan pendapatan rumah tangga (income generating).
Rumah tangga yang mendapatkan Beras Raskin tidak serta merta menjadi semakin tinggi tingkat pendapatannya. Namun, tingkat konsumsi yang tercermin dari pengeluaran rumah tangga semakin baik akibat dari program ini. Jalur distribusi Raskin yang kerap terkendala menjadi salah satu pemicu kurang efektifnya program ini menyentuh sisi pendapatan.

\section{KESIMPULAN DAN SARAN}

Bedasarkan hasil penelitian yang dilakukan maka dapat ditarik beberapa kesimpulan terkait dengan Program Raskin. Pertama, sebagai program yang dirancang untuk menahan agar tingkat konsumsi masyarakat tidak jatuh saat krisis ekonomi, Program Raskin dapat dikatakan cukup berhasil memenuhi tujuan tersebut. Hasil estimasi menunjukkan bahwa rumah tangga yang memperoleh fasilitas Beras Raskin memiliki tingkat konsumsi atau pengeluaran rumah tangga yang lebih baik. Kedua, jika program ini digunakan untuk mempertinggi pendapatan rumah tangga maka bukti statistik menunjukkan bahwa program ini terbukti belum memiliki dampak terhadap peningkatan pendapatan rumah tangga.

Terkait dengan posisi Provinsi Bali yang memiliki tingkat kemiskinan relatif rendah secara nasional, Program Raskin masih layak untuk dilanjutkan karena memiliki potensi sebagai penyangga saat krisis. Tipe kemiskinan di Provinsi Bali yang lebih banyak bersifat near poor masih sangat rentan terhadap gejolak. Sebagai antisipasi, program stabilisasi pangan seperti Raskin masih dapat digunakan. Hasil penelitian di Bali secara konsisten menunjukkan bahwa Program Raskin memiliki efek positif terhadap konsumsi dibandingkan pendapatan.

Penelitian ini masih belum menyentuh diskusi mengenai kinerja penyaluran Beras Raskin secara menyeluruh. Dalam hal ini, apakah daerah yang memiliki tingkat kemiskinan lebih tinggi memang memperoleh jatah Beras Raskin yang lebih banyak atau sebaliknya. Sebagai suatu saran, penelitian lanjutan dapat dilakukan untuk menguji hipotesis ini guna memperkuat temuan sebelumnya.

\section{REFERENSI}

Abdulai, A., Barret, C., \& Hoddinott. (2005). Does Food Aid Really Have Disincentive Effect? New Evidence from Sub-Saharan Africa. I 
Word Development , 33, 1689-1704.

Barret, C. (2002). Food Aid Effectiveness: It's targeting, stupid. New York: Departement of Applied Economics and Management, Cornell University.

Barret, C., \& Maxwell. (2005). Food Aid After Fifty Years: Recasting its Role. London: Routledge.

Blundell, R., \& MaCurdy, T. (2000). Labor Supply: A Review of Alternative Approaches. Dalam D. Ashenfelter, \& D. Card, Hanbook of Labor Economics (hal 1559-1695). Amsterdam: North-Holland.

Dercon, S., \& Krishnan, P. (2003). Risk Sharing and Public Transfers. Econoomic Journal , 113, C86-C94.

Gerardi, K., \& Tsai, Y. (2010). The Effect of Social Entitlement Programs on Private Transfers: New Evidence of Crowding Out. Atlanta: Federal Reserve Bank of Atlanta.

Gilligan, D. O., \& Hoddinott. (2007). Is there Persintence in Impavt of Emergency Food Aid? Evidence on Consumption, Food Security and Assets in Rural Ethiopia. American Journal of Agricultural Economics, 89, 225-242.

Kang, S. J. (2004). Are Private Transfer Crowdedout by Public Transfer?: The Case of Nepal. The Developing Economies , XLII-4, 510-528.

Kang, S. J., \& Suwada, Y. (2003). Are Private Transfers Altruistically Motivated? The Case of Republic of Korea Before and During the Financial Crisis. The Developing Economies , XLI-4, 484-501.

Khander, S. R., Koolwal, G. B., \& Samad, H. A. (2010). Handbook on Impact Evaluation, Quantitative Methods and Practices. Washington DC: The World Bank.
Lal, D., \& Sharma, A. (2009). Private Household Transfers and Poverty Alleviation in Rural India: 1998-99. The Journal of Applied Economic Research, 97-112.

Lentz, E. (2003). Annotated Bibliography of Food Aid Disincentive Effect. New York: Cornell University.

Mawardi, S. (2008). Efektivitas Pelaksanaan Raskin. Jakarta: SMERU.

Nielsen, M. E., \& Olinto, P. (2007). Do Conditional Cash Transfers Crowd-out Private Transfers?: Evedence from Randomize Trials in Honduras and Nicaragua. Washington: World Bank .

Quartey, P. (2006). Migrant Remittances and Household Welfare in Times of MacroVolatility: The Case of Ghana. ISSER University of Ghana Legon .

Sahn, D. E., \& Alderman, H. (1996). The Effect of Food Subsidies on Labor Supply in Sri Lanka. Economic Development and Cultural Change , 45, 125-145.

Skoufias, E., Unar, M., \& Gonzales, T. (2008). The Impact of Cash and In-kind Transfers on Consumption and Labor Supply. Washington: World Bank.

Sulaiman, M. (2010). Incentive and Crowdingout Effects of Food Assistance: Evidence from Randomized Evaluation of Food-forTraining Project in Southern Sudan. London: Economic Organisation and Public Policy Programme.

Tadesse, G., \& Shively, G. (2009). Food Aid, Food Prices and Producer Disincentive in Ethiopia. American Journal of Agricultural Economics , 91, 942-955. 